\title{
Strong medicine for China's journals
}

Few Chinese scientists would be surprised to hear that many of the country's scientific journals are filled with incremental work, read by virtually no one and riddled with plagiarism. But the Chinese government's solution to this problem came as a surprise last week.

Li Dongdong, a vice-minister of state and deputy director of the General Administration of Press and Publications (GAPP) - the powerful government body that regulates all publications in China acknowledged that the country's scientific publishing had a "severe" problem, with "a big gap between quality and quantity", and needed reform.

Opening a meeting of scientific publishers in Shanghai on 7 September, Li announced that by January 2011, new regulations will be used to "terminate" weak journals.

Precisely how this reform will work is the subject of hot debate. If an evaluation process finds a journal to be weak, it may be forced to close altogether, or relaunch with a different editorial board, a different title or even a different subject focus.

Those journals judged to be strong will receive support such as tax breaks. Scientific publishing will be concentrated in "five-to-ten large publishing groups" that will compete with each other, says Li. "We will turn China from a large science and technology publisher to a powerful science and technology publisher." GAPP did not respond to Nature's requests for more information.

News of the regulation startled many of the publishers at last week's meeting, the 6th China Science Journal Development Forum. Some believe that bureaucrats should not be interfering with journals, and others say that powerful scientists will resist the move. But all agreed that China's scientific publishing is in bad shape.

Approximately one-third of the roughly 5,000 predominantly Chinese-language journals are 'campus journals', existing only so that graduate students and professors can accumulate the publications necessary for career advancement, according to one senior publisher. And in a Correspondence to Nature last week, Yuehong Zhang of the Journal of Zhejiang University-Science reported that a staggering $31 \%$ of the papers submitted to that campus journal contained plagiarized material (Nature 467, 153; 2010).

Most Chinese journals make their money through funding from their host institutions, and by charging authors perpage publishing fees. "Most are never cited. Who knows if they're even really published. They're ghosts," says one publisher, who declined to be named. Wu Haiyun, a cardiologist at the Chinese PLA General Hospital in Beijing, says that only 5-10\% of these journals are worth saving, and the rest are "information pollution".

Most of China's top researchers already forgo Chinese publications for international ones, where they earn the recognition that can promote their career. And they are increasingly successful: in November 2009, scientists from China became the secondmost prolific publishers of scientific articles in international scientific journals.

But some Chinese librarians are beginning to baulk at the prices charged by these foreign journals. On 1 September, an

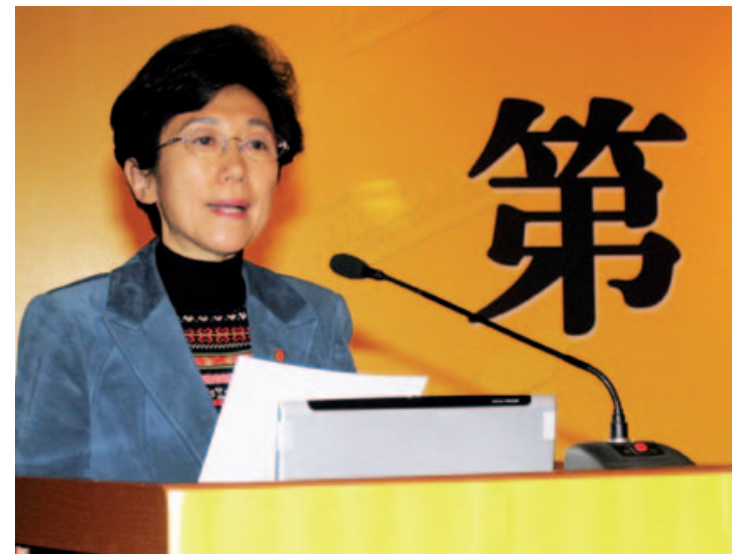

Li Dingdong plans major reforms for Chinese publishing.

open letter signed by 35 librarians criticized foreign science, technology and medicine publishers for "using their monopolistic position" to raise subscription prices annually by more than $14 \%$ for the next 3 years. Meanwhile, some of the better Chinese journals are being published in collaboration with foreign companies such as Wiley-Blackwell and Springer, respectively headquartered in Hoboken, New Jersey, and Berlin. Cell Research, for example, based at the Shanghai Institutes for Biological Sciences and co-published by Nature Publishing Group, reached an impact factor of 8.2 in 2009 - the highest in the Asia-Pacific region, including Australia. Impact factors could provide an important cornerstone of the government's evaluation system. For example, the Chinese Journal Citation Report, published by the Institute of Scientific and Technical Information of China since 2004 and covering some 1,800 of China's top journals, provides impact factors that measure their significance on the basis of the number of times that articles are cited by peers.

Many Chinese journals are switching to publishing in English to increase their impact factors, and more than 200 Englishlanguage science and technology journals are now based in China. ACTA Genetica Sinica became the Journal of Genetics and Genomics in 2007; Neuroscience Bulletin, founded in 1998, switched to English in 2006; and in January 2009, Acta Zoologica Sinica, published since 1935 and the secondoldest journal in China, became Current Zoology. In its first year, the proportion of papers that it published from non-Chinese scientists shot up from $16 \%$ to $42 \%$. Having earned a spot on the list of journals counted by Thomson Reuters Web of Knowledge, the journal is awaiting its first impact factor. Martin Stevens, a zoologist at the University of Cambridge, UK, says that Current Zoology is now finding a niche.

"Before, there weren't any journals that had this relatively broad audience. Many looked at specific areas of biology," says Stevens, who guest edited a special issue of the journal about how the sensory system relates to evolution.

A minority of Chinese scientists argue that there is no need for Chineselanguage primary research journals at all. All original Chinese research should be published in English-language journals to get the widest audience possible, says $\mathrm{Wu}$, who adds that Chinese-language journals should stick to publishing continuing education and review articles. "Is it necessary for China to have its own journals?" he asks.

The government's answer is an emphatic 'yes'. For Li, strong scientific publishing is a necessary "driving force in innovation and technological strength". Once the new reforms are under way, she says, "journals will be a strong part of our soft power". David Cyranoski

See Editorial, page 252. 